\title{
Early responses of biodiversity indicators to various thinning treatments in mountain beech forests
}

\author{
Fabio Lombardi ${ }^{(1)}$, \\ Stefania Di Lella ${ }^{(2)}$, \\ Valeria Altieri ${ }^{(1)}$, \\ Simone Di Benedetto ${ }^{(1)}$, \\ Carmen Giancola ${ }^{(2)}$, \\ Bruno Lasserre ${ }^{(2)}$, \\ Lado Kutnar ${ }^{(3)}$, \\ Roberto Tognetti ${ }^{(4-5)}$, \\ Marco Marchetti ${ }^{(2)}$
}

\begin{abstract}
In recent decades, the conservation of biodiversity has become one of the main areas under consideration in managing forests in an ecologically sustainable way. Forest management practices are primary drivers of diversity and may enhance or decrease forest biodiversity, according to the measures applied (thinning options). We have focused on three beech (Fagus sylvatica L.) forests across a latitudinal gradient in Italy, characterised by different structures resulting from dissimilar management. We tested the short-term effects of differently-based silvicultural intervention vs. stands where no silvicultural practices were applied on biodiversity indicators and related proxies: deadwood amounts, microhabitat density, floristic richness and life form abundance. In each study area, the occurrence of the above indicators and proxies was evaluated before and after the implementation of crop tree thinning (CTT) and thinning from below (LT) methods, comparing them with control areas where no interventions were performed. After two years, the management options resulted in different responses of the investigated parameters. The CTT increased deadwood amounts in comparison with the LT ones, while stumps increased significantly after the LT thinning. Microhabitats increased significantly where intervention was not undertaken. On the contrary, they remained unaltered after the LT treatments. CTT thinning created favourable conditions for the development of microhabitats and their proliferation in the long term. Two years after the application of the CTT thinning treatment, all forest stands demonstrated a significant increase in their floristic richness and herb layer cover. Significant differences were also found in both the frequency and cover of life forms in relation to silvicultural treatment. These findings provide a better understanding of short-term effects of silvicultural treatment useful for maintaining biodiversity in mountain beech forests.
\end{abstract}

Keywords: Deadwood, Microhabitats, Understory Vegetation, Mountain Forests, Sustainable Forest Management, Italian Forests

\section{Introduction}

Forests are the most important global repository of terrestrial biodiversity, which play an important role in functional ecosystems and the supply of a wide range of ecosystem services (Pecl et al. 2017). Climate and land use changes are threatening forest biodiversity, with negative effects on forest productivity and carbon uptake. The conservation of biodiversity is, therefore, a major goal when managing forests in a sustainable way (Lindenmayer et al. 2000). Sustainable forest management needs to integrate forest conservation

(1) Dipartimento di Agraria, Università Mediterranea di Reggio Calabria, loc. Feo di Vito, 89122, Reggio Calabria (Italy); (2) Dipartimento di Bioscienze e Territorio, Università degli Studi del Molise, c.da Fonte Lappone, 86090, Pesche - IS (Italy); (3) Slovenian Forestry Institute, Dep. of Forest Ecology, Vecna pot 2, 1000 Ljubljana (Slovenia); (4) Dipartimento di Agricoltura, Ambiente e Alimenti, Università degli Studi del Molise, v. Francesco De Sanctis, 86100, Campobasso (Italy); (5) The EFI Project Centre on Mountain Forests (MOUNTFOR), Edmund Mach Foundation, 38010, San Michele all'Adige - TN (Italy)

@ Fabio Lombardi (fabio.lombardi@unirc.it)

Received: Jan 19, 2018 - Accepted: Jun 26, 2018

Citation: Lombardi F, Di Lella S, Altieri V, Di Benedetto S, Giancola C, Lasserre B, Kutnar L, Tognetti R, Marchetti $M$ (2018). Early responses of biodiversity indicators to various thinning treatments in mountain beech forests. iForest 11: 609-618. - doi: 10.3832/ifor2733-011 [online 2018-09-25]

Communicated by: Agostino Ferrara

practices based on multi-functional and flexible approaches (MacDicken et al. 2015), including potential values of climate regulation, habitat provision, water control, genetic resources, etc. Indeed, forest management is an important factor that influences richness in species and ecosystem productivity and, in relation to the applied measures, may have positive or negative effects on forest biodiversity (Kutnar et al. 2015). Silvicultural strategies and conservation priorities focusing on site-specific guidelines for stand structures and harmonised use of the forest resources are recommended for achieving the required objectives in resilience and inclusiveness. Furthermore, they may mimic the processes naturally occurring in forest ecosystems (Gamborg \& Larsen 2003).

When considering the multi-functionality of forest systems, different types of management can be applied to preserve forest functions and timber production in mountain environments. Sustainable forest management practices should be used to promote the conservation of biological forest resources on a global scale. At the local scale, forest management guidelines and 
forest certification programs may require maintaining or increasing the abundance of deadwood as an indicator of progress in maintaining biodiversity. Intensively managed forests show a reduction in the amount and variety of deadwood in comparison with unmanaged forests (Paillet et al. 2015), even though it is a key structural feature in forest ecosystems that supports species diversity (Burrascano et al. 2008, Lombardi et al. 2012).

Deadwood occurrence is essential for the maintenance of biodiversity, representing a source of nutrients for invertebrates ( $\mathrm{Si}$ itonen 2001), bryophytes (Odor \& Standovár 2001) and lichens (Humphrey et al. 2002). Deadwood substrates serve as a refuge that hosts a wide diversity of animals, such as amphibians (Herbeck \& Larsen 1999), small mammals (Harmon et al. 1986), and birds (Mikusinski \& Angelstam 1997). Deadwood amounts continuously evolve in time, not only in relation to the intensity of silvicultural practices and the way they are carried out (Guby \& Dobbertin 1996), but also due to the frequency, intensity and type of natural disturbances. Furthermore, the loss of microhabitats threatens biodiversity in forest ecosystems (Winter \& Möller 2008). The term "microhabitat" encompasses several structural features on single trees and small substrates used by numerous species, or groups of species, to grow, nest or forage (Winter \& Möller 2008). Microhabitats can be associated with decreasing tree vitality, which is commonly caused by a combination of fungi, viruses and bacteria (Larrieu $\&$ Cabanettes 2012). They are useful in describing the level of forest naturalness, integrating structural complexity and deadwood diversity (Michel \& Winter 2009). Dying or dead trees offers a great variety of tree holes, which necessarily attract cavity nesting or roosting birds, and support large invertebrate communities. Decaying deadwood provides nutrients and moisture that benefit many organisms, as well as shelter in extreme temperatures.

Understory vegetation is also a component of forest biodiversity and a key driver of many forest processes, including litter decomposition (Dearden \& Wardle 2008), light interception (Gendron et al. 1998) and forest productivity (Nilsson \& Wardle 2005). Understory vegetation constitutes the largest number of plant species that participate in forest dynamics. Single species or groups of species growing on the forest floor can be used as proxies for site conditions (Khanina et al. 2007). Identifying the occurrence of plant species in the forest understory provides an assessment of the degree of naturalness, addressing suitable management models for the conservation of biodiversity (Nilsson \& Wardle 2005). Forest management has a strong effect on floristic composition and, in particular, on the abundance of life form (Kern et al. 2014). Thinning activities, as well as natural disturbances, alter forest floor microclimatic conditions, promoting higher understory species densities (and deadwood decomposition rates), which in turn can affect other processes and taxa. However, our understanding of how silvicultural treatments affect biodiversity indicators and how these effects interact with natural disturbances is limited, particularly in the Mediterranean area.

The conservation of biodiversity in forests, therefore, requires investigation to define innovative silvicultural treatments that promote conservation purposes (Lindenmayer et al. 2000). In this study, we tested the short-term effects of differentlybased silvicultural interventions (innovative and traditional) vs. stands where no silvicultural practices were applied on biodiversity indicators and related proxies. Specifically, we quantified the amount of deadwood, the density and variability of microhabitats, understory vegetation composition and the abundance of life forms

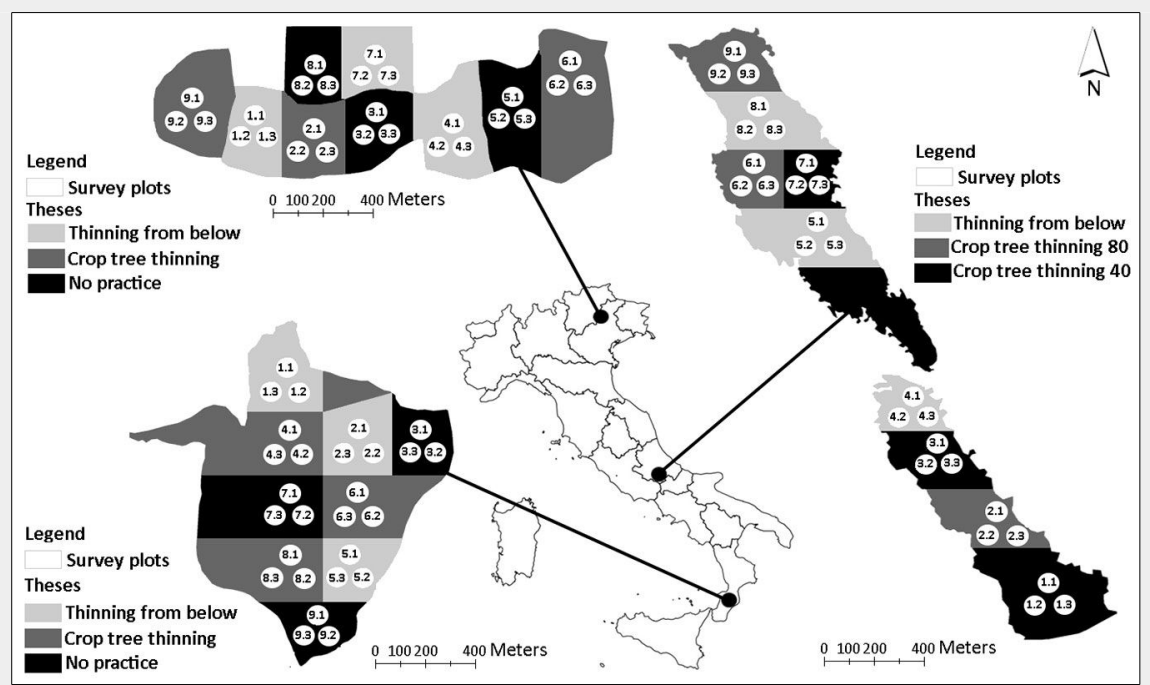

Fig. 1 - Location of the three study sites and the survey protocol applied in Cansiglio (a), Chiarano-Sparvera (b) and Mongiana (c). before and after different types of forest thinning were applied to three mountain beech forests located along a latitudinal transect that stretches from southern to northern Italy. We hypothesised that the density of microhabitats, the amount of deadwood, the richness of species and the abundance of life forms would be reduced and simplified in relation to the intensity and type of applied silvicultural treatments.

\section{Materials and methods}

\section{Study sites}

The investigations was carried out in three study sites located across a latitudinal transect in Italian mountain beech forests (Fig. 1), corresponding to different bioclimatic regions. In detail, they represent three different habitats (sensu Habitats Directive 92/43 ECC): 9130 AsperuloFagetum Fagus sylvatica forests for the Alpine site, 9210 Apennine beech Fagus sylvatica forests with Taxus and Ilex for Central Apennine and 9220 Apennine Fagus sylvatica forests with Abies alba for Southern Apennine.

The northern study site of the transect is located in the Cansiglio area, in the Southern Alps (Veneto Region). The forest extends to 667 ha and is characterised by a high forest, where beech (Fagus sylvatica L.) is the dominant tree species. The forest consists of an even-aged (120 to 145 years) stand, where low-mixed thinning is repeated every 20-25 years on the same management unit. The long-lasting repetition of silvicultural practices resulted in a fairly uniform stand structure (Becagli et al. 2013).

The Chiarano-Sparvera site is located in Central Italy, in the Apennine mountains (Abruzzo Region), included in the external protection zone of the "Abruzzo, Lazio and Molise" National Park. The total area extends to 766 ha, covered mainly by beech (95\%). The principle historical management type is coppice with standards, although it is currently characterised by an even-aged high forest arising from a conversion treatment.

The Mongiana study site is located in the Southern Apennine (Calabria Region). The stand is a high forest dominated by beech that extends over an area of 1257 ha. Being located in the upper part of the mountain system facing the Tyrrhenian sea, its microclimate is influenced by the interception of fog, wet winds and precipitation (Becagli et al. 2013). The stand is even-aged (about 70 years) with trees from the former cycles are still present. The random occurrence of trees much older than the dominant tree age makes the physiognomy less regular than a typical even-aged beech forest (Becagli et al. 2013).

Details on the main features of the study areas are reported in Tab. 1. 
Survey scheme and types of treatments

Fig. 1 reports the survey approach applied in the three study sites. An area of 30 hectares was devoted to the management trials at each site. Three silvicultural treatments (theses) were identified and randomly assigned in three replicates to each compartment. Each sector was defined using a 3-ha grid. In each sector, a cluster of three circular sampling plots $\left(530 \mathrm{~m}^{2}\right)$ was established within each compartment, according to a systematic design (Becagli et al. 2013, Lombardi et al. 2015). A total of 81 plots were then sampled: 27 for each study area, 9 plots for each compartment ( 9 plots $\times 3$ compartments $\times 3$ study areas). In each study area, the traditional treatments were compared to an "innovative" silvicultural intervention, with the exception of Chiarano-Sparvera site, where two innovative interventions where applied (see below). Traditional logging consisted in selective thinning (from below), reducing forest density through the removal of selected trees, but maintaining a homogeneous canopy cover. Innovative treatments consisted of opening canopy gaps (thinning from above), releasing candidate trees selected on the basis of their dominance and structure (shape, position, quality), and harvesting all adjacent trees.

In particular, one silvicultural treatment was characterised by the customary thinning practice (i.e., low-mixed thinning $\mathrm{LT}$ ), as applied by local managers. The second silvicultural option consisted of a crown thinning at the Cansiglio site and in the selection of $45-50$ trees per ha, with the removal of direct competitors at the Mongiana site. The no-thinning area ("No practice"), used as control, was not present at the Chiarano-Sparvera site, where two innovative methods were applied together with the LT treatment. In the latter site, the crop tree treatments (CCT) used were the "CTT 40" and the "CTT 80", consisting of a selective thinning which was applied to support the best 40 trees per hectare and the best 80 trees per hectare, respectively. For further details on the differences between the LT and CTT silvicultural approaches and related harvested forest biomass, see $\mathrm{Di}$ Salvatore et al. (2016).

Additionally, deadwood was artificially enriched near the ground in all the "innovative" treatments, by leaving both coarse woody debris and dead trees lying on the forest floor. All wood was taken from freshly felled trees. Moreover, 2-3 living stems per hectare were girdled to create standing dead trees, or felled and left on the ground to establish microhabitats and corridors for saproxylic insects and microfauna.

In order to test the effectiveness of management options, the biodiversity indicators and proxies (deadwood, microhabitats and understory vegetation) were sampled before and after the silvicultural interventions. More specifically, the effects of the

Tab. 1 - Main geographic features of the three investigated sites located across a latitudinal transect in Italian mountain beech forests. Site 1 is located in the Southern Alps (Veneto); site 2 in Central Italy, on the Apennine mountains (Abruzzo), while the Site 3 refers to the Southern Apennine (Calabria).

\begin{tabular}{lccc}
\hline Characteristic & $\begin{array}{c}(\mathbf{1}) \\
\text { Cansiglio }\end{array}$ & $\begin{array}{c}\mathbf{( 2 )} \\
\text { Chiarano-Sparvera }\end{array}$ & $\begin{array}{c}\mathbf{( 3 )} \\
\text { Mongiana }\end{array}$ \\
\hline Area (ha) & $\sim 33$ & $\sim 30$ & $\sim 30$ \\
\hline Coordinates & $46^{\circ} 03^{\prime} \mathrm{N}$ & $41^{\circ} 51^{\prime} \mathrm{N}$ & $38^{\circ} 30^{\prime} \mathrm{N}$ \\
(UTM-WGS84) & $12^{\circ} 23^{\prime} \mathrm{E}$ & $13^{\circ} 57^{\prime} \mathrm{E}$ & $16^{\circ} 14^{\prime} \mathrm{E}$ \\
\hline Altitudinal range (m a.s.l.) & $1100-1200$ & $1700-1800$ & $\sim 1100$ \\
\hline Exposure & North & North-East & North-West \\
\hline Bedrock & Limestone, & Cretaceous & Granite \\
& Marlstone & limestone & 101 \\
\hline Mean annual temperature $\left({ }^{\circ} \mathrm{C}\right)$ & 56 & 85 & 1880 \\
\hline Annual precipitation $(\mathrm{mm})$ & 1660 & 1000 & \\
\hline
\end{tabular}

thinning intervention were tested two years after the silvicultural treatments were performed.

\section{Deadwood and microhabitats}

In each plot, deadwood was assessed according to the following parameters: standing dead trees, downed dead trees, coarse woody debris (CWD) and stumps (Tab. 2).

Standing dead trees, downed dead trees and stumps were included in the survey when more than half of the base of the trunk lay within the plot. Coarse woody pieces were included when more than half of the base of the thicker end lay within the plot. A threshold height of $1.3 \mathrm{~m}$ was used to distinguish stumps (less than $1.3 \mathrm{~m}$ ) from standing dead trees (higher than 1.3 $m$ - Lombardi et al. 2012).

The volume of standing and downed dead trees was calculated using the equations derived for the prediction of the aboveground tree volume (Tabacchi et al. 2011). Moreover, the volume of stumps and coarse woody debris was calculated using the following equation (eqn. 1 ):

$$
V=\frac{1}{3} \pi h\left(R^{2}+r R+r^{2}\right)
$$

where $V$ is the volume $\left(m^{3}\right) ; h$ is the height or length $(\mathrm{m}) ; R$ is the maximum radius $(\mathrm{m}) ; r$ is the minimum radius $(\mathrm{m})$. Volumes in $\mathrm{m}^{3}$ were converted into volumes per hectare by applying an expansion factor, they were then grouped in relation to the different silvicultural treatments.

Tab. 2 - Deadwood attributes sampled before and after the thinning operations. A total of 81 plots were realized: 27 for each study area, 9 plot for each compartment ( 9 plots $\times 3$ compartments $\times 3$ study areas $)$. $\left(\mathrm{dbh}_{130}\right)$ : diameter at breast height; $(\mathrm{H})$ : height; ( $L)$ : length; $\left(D_{\min }\right)$ : minimum diameter; $\left(D_{\max }\right)$ : maximum diameter; $\left(D_{\text {base }}\right)$ : diameter at the base of the trunk; $\left(D_{\text {top }}\right)$ : diameter at the top of the trunk.

\begin{tabular}{lll}
\hline Deadwood component & Dimensional limits & Parameters recorded \\
\hline Dead downed trees & $\mathrm{dbh}_{130} \geq 5 \mathrm{~cm}, \mathrm{~L} \geq 130 \mathrm{~cm}$ & Species, $\mathrm{dbh}_{130}, \mathrm{~L}$ \\
Standing dead trees & $\mathrm{dbh}_{130} \geq 5 \mathrm{~cm}, \mathrm{H}>130 \mathrm{~cm}$ & Species, $\mathrm{dbh}_{130}, \mathrm{H}$ \\
CWD (Coarse Woody Debris) & $\mathrm{D}_{\min } \geq 5 \mathrm{~cm}, \mathrm{~L} \geq 100 \mathrm{~cm}$ & Species, $\mathrm{D}_{\min }, \mathrm{D}_{\text {max }}, \mathrm{L}$ \\
Stumps & $\mathrm{D}_{\text {top }} \geq 5 \mathrm{~cm}, \mathrm{H} \leq 130 \mathrm{~cm}$ & Species, $\mathrm{D}_{\text {base }}, \mathrm{D}_{\text {top }}, \mathrm{H}$ \\
\hline
\end{tabular}


were structured into five macro-categories of life form: chamephytes (Ch), geophytes $(G)$, hemicryptophytes $(H)$, phanerophytes $(\mathrm{P})$, and terophytes $(\mathrm{T})$, according to Raunkiaer's classification. Finally, the cover of herbaceous layer, species richness (number of species), frequency and cover for each life-form group were calculated for each plot and at site level, before and after the thinning interventions.

\section{Statistical analysis}

In order to evaluate the effects of the silvicultural treatments for each geographical area investigated, the amounts of deadwood and microhabitats obtained before (ex-ante) and after (ex-post) the intervention phases were compared using the software SPSS Statistics ${ }^{\circledast}$ ver. 20.0 (IBM Corp., Armonk, NY, USA). The herb layer cover, the floristic richness and the biological spectrum relating to frequency and species coverage were also assessed, at site level, both before and after the silvicultural treatments.

Normal distribution of variables in each population was tested using the ShapiroWilk normality test. When no significant departure was detected, parametric comparison methods were adopted; otherwise, non-parametric comparison tests were used. Post-hoc mean comparison tests were performed by Tuckey HSD test, when statistically significant differences between group means were found by one-way ANOVA. When variables had non-Gaussian distribution and the non-parametric Kruskal-Wallis test revealed differences among populations, post-hoc comparisons were performed using the Dunn's test.

\section{Results}

\section{Deadwood amounts}

We observed different results related to the silvicultural treatments. Data collected before the treatments showed a high variability in volume among the different deadwood components (Fig. 2). After the application of silvicultural treatments, differences in deadwood volumes were found among the study sites.
In Cansiglio (Fig. 2a), stumps ranged between 17.94 and $21.05 \mathrm{~m}^{3} \mathrm{ha}^{-1}$ in the CTT and LT treatments, respectively. The volume of stumps was significantly higher following the CTT and LT treatments $(p<0.01$ and $p<0.05$ ), while it did not vary for the control without interventions ("No practice" treatment). Moreover, volumes of downed dead trees significantly increased to $7.60 \mathrm{~m}^{3}$ ha $^{-1}$ after the CTT treatment $(p<0.01)$.

In Chiarano-Sparvera (Fig. 2b), results revealed a scarce presence of downed dead trees, both before and after the treatments, with a total absence in the CTT80 treatment. Before the silvicultural treatments, coarse woody debris volume showed a mean of only $5.5 \mathrm{~m}^{3} \mathrm{ha}^{-1}$. Silvicultural treatments lead to a drastic reduction of coarse woody debris after the low thinning (LT) approach, with a significant decrease $(p<0.05)$ of $4.60 \mathrm{~m}^{3} \mathrm{ha}^{-1}$. In the other two sites, such result after the LT treatment was not observed. The volume of stumps did not increase after the treatment, while it was significantly higher for

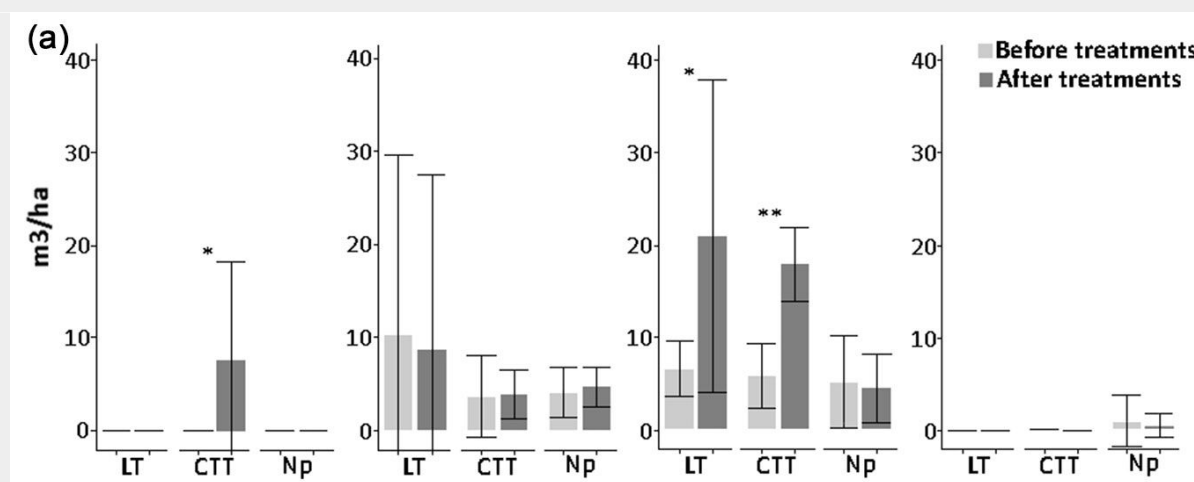

Fig. 2 - Amount $\left(\mathrm{m}^{3} \mathrm{ha}^{-1}\right)$ of deadwood components before and after the cutting activities at Cansiglio (a), ChiaranoSparvera (b) and Mongiana (c) sites, with related statistical comparisons. $(*): p<0.05 ;(* *): p<0.01$.

(b)

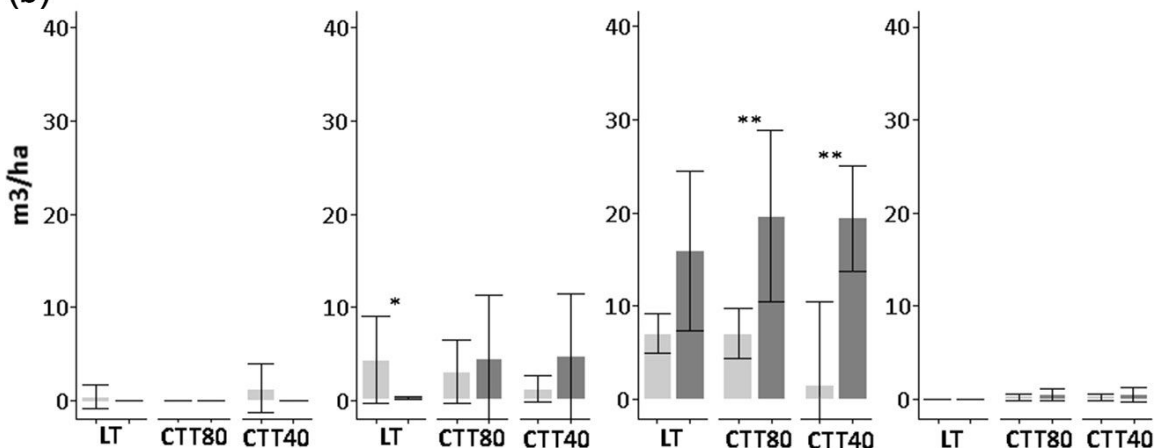

(c)

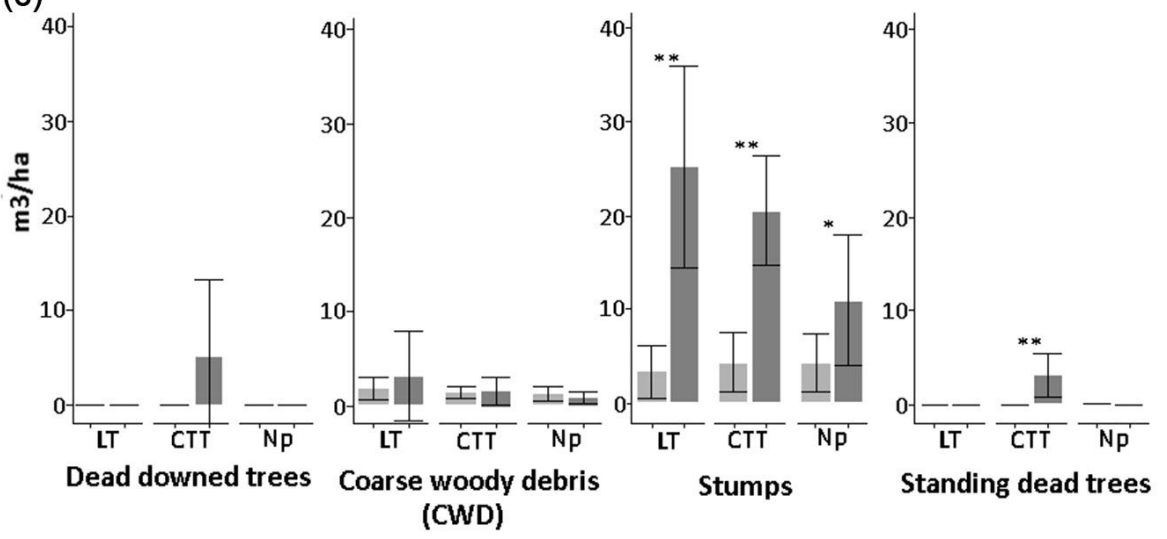


Fig. 3 - Total density $\left(\mathrm{N} \mathrm{ha}^{-1}\right)$ of microhabitats and statistical differences in the three sites, before and after silvicultural intervention. $\left(^{*}\right)$ : $p<0.05 ;(* *)$ : $\mathrm{p}<0.01$.

both the CTT40 $(p<0.01)$ and CTT80 $(p<0.01)$ treatments. The amount of standing dead trees was low before the silvicultural treatments and did not vary significantly thereafter.

All the silvicultural treatments applied in Mongiana lead to a significant increase in the volume of stumps (Fig. 2c). In detail, a significant increase $(p<0.01)$ of about $15 \mathrm{~m}^{3}$ ha $^{-1}$ was observed after the innovative treatment; in the "No practice" area, increases of nearly $20 \mathrm{~m}^{3} \mathrm{ha}^{-1}(\mathrm{p}<0.01)$ and 5 $(p<0.05) \mathrm{m}^{3} \mathrm{ha}^{-1}$ were observed, respectively. The volume of standing dead trees increased significantly to about $3 \mathrm{~m}^{3} \mathrm{ha}^{-1}$ $(p<0.01)$ only after the innovative treatment. The volume of downed dead trees increased to $5 \mathrm{~m}^{3}$ ha-1 after the innovative treatment, although the increase was not statistically significant.

\section{Microhabitats}

In general, a high variability in the number of microhabitats per hectare was observed in the study sites, although less evidently for Cansiglio, both before and after the silvicultural treatments (Fig. 3).

No significant differences were observed after the low thinning (LT) treatment for all

\section{Total number of microhabitats/ha}

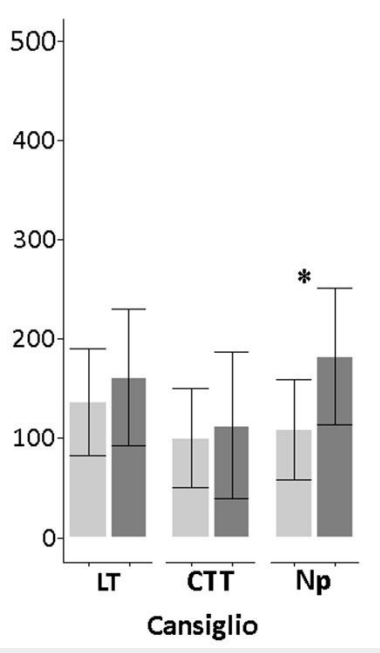

three study sites. Both before and after silvicultural treatments, the total number of microhabitats was around 150 elements per hectare in Cansiglio and ChiaranoSparvera, while it was higher in Mongiana (about 230 microhabitats ha ${ }^{-1}$ ).

On the contrary, in Cansiglio and Mongiana a significant increase in the number of microhabitats was observed where the silvicultural treatments were not undertaken. Particularly, the number of microhabitats in Cansiglio increased $(p<0.05)$ to about 70 units ha ${ }^{-1}$, while in Mongiana the number of microhabitats reached nearly 220 units ha $^{-1}$, with an increase of about 90 microhabitats $(p<0.05)$.

Thinning from above did not produce a significant increase in the number of microhabitats after the innovative treatment in Cansiglio, while a significant decrease $(p<0.05)$ in the number of microhabitats was observed in Chiarano-Sparvera following both innovative treatments.

In particular, a marked decrease from 300 to less than 130 microhabitats per hectare was observed after the CTT80 treatment.

Species richness and cover

Before the silvicultural treatments, a total of 178 plant species was recorded in all vegetation plots. Comparing the three sites, different effects were observed, particularly concerning the type of treatments and species richness (Fig. 4).

In Cansiglio, the innovative treatments lead to a significant increase $(p<0.05)$ in species richness with a mean of about 26 , while in Mongiana the increase was marginal. In Chiarano-Sparvera, the increase of species richness was significant after all silvicultural treatments. Significant increases $(p<0.01)$ were observed after the low thinning and CTT40 treatments. with a mean of 20.1 and 22.1, respectively, while a significant increase $(p<0.05)$ with a mean of 17.6 was recorded in the CTT80 treatment. Significant increases in plant cover species were recorded in all sites with a medium increment of $55 \%$ (Fig. 5). The total plant cover is often higher than $100 \%$, since all vegetation layers, which frequently overlap, were considered as the sum of the cover values for each sampled species/ layer.

In Chiarano-Sparvera plant species-cover increased significantly $(p<0.01)$ after all silvicultural treatments. In Cansiglio, a significant increase was observed after both low
Fig. 4 - Number of species recorded before and after the silvicultural treatment in the three study sites, with related statistical comparisons. (*): $p<0.05 ;(* *): p<0.01$

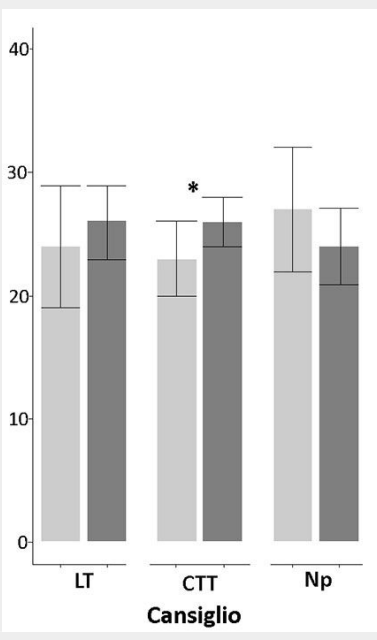

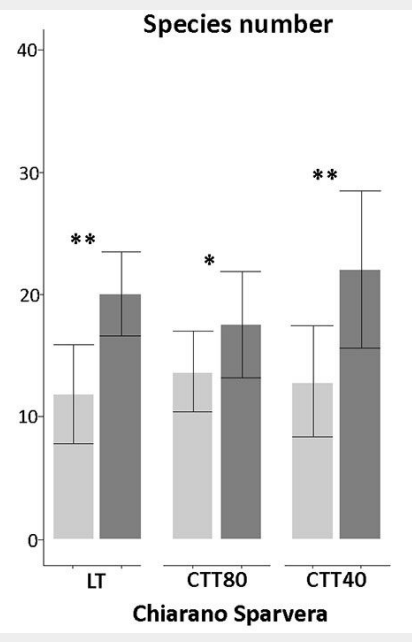

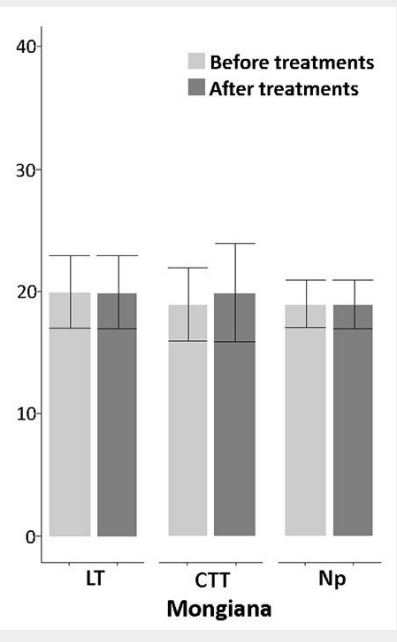




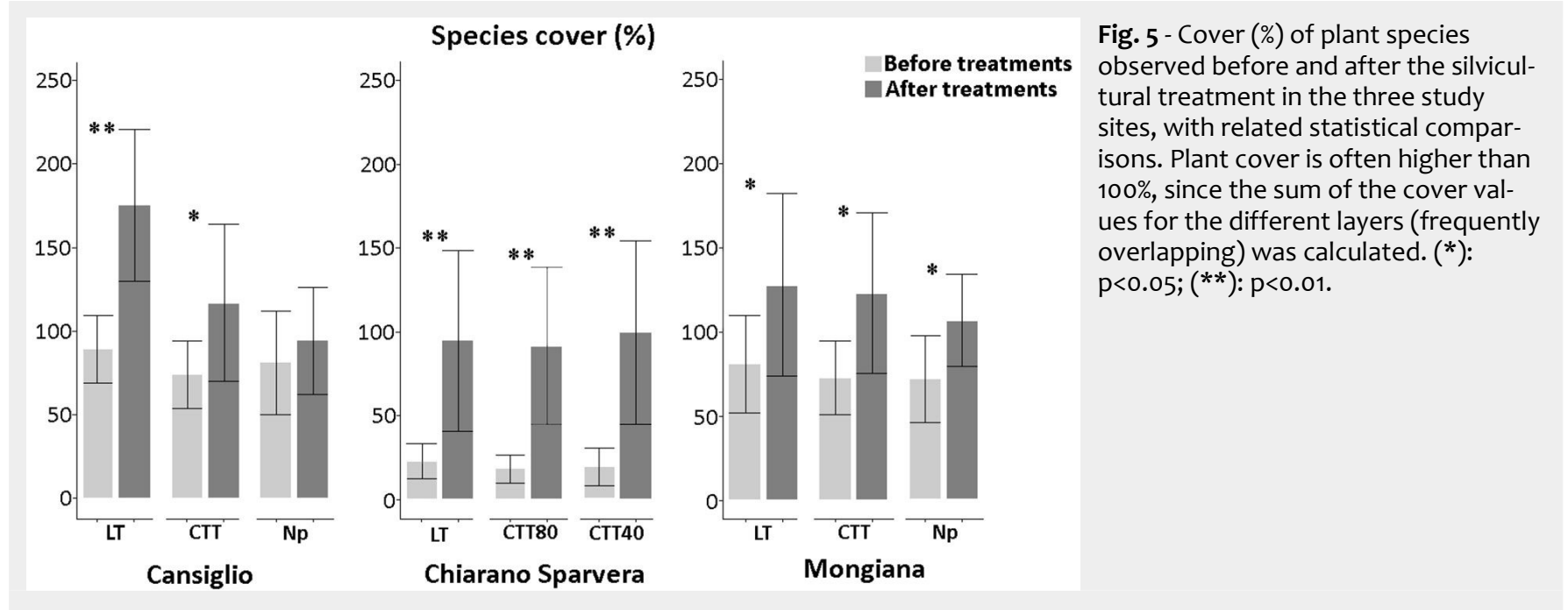

thinning $(p<0.01)$ and crop tree thinning the frequency of life forms for the three $(p<0.05)$ treatments. By contrast, in Mon- studied sites (data not shown).

giana, a significant increase in plant species-cover was observed after low thinning, innovative and "No practice" treatments $(p<0.05)$.

\section{Life forms}

Two years after the silvicultural treatment, significant differences were found in
In all sites, after the innovative treatment the frequency of therophytes was higher $(p<0.01)$ than other life forms. The majority of these species appeared in the canopy gaps. In Cansiglio, a higher frequency of geophytes and lower frequency of hemicryptophytes were detected in the control plots. In Chiarano-Sparvera, hemicrypto- phytes increased after CTT80 (on average by $12.78 \%$ ) and CTT40 (on average by $15.89 \%$ ) treatments, with a decrease of geophytes after all the silvicultural treatment: low thinning (on average by $1.56 \%$ ), CTT80 (on average by $1.89 \%$ ) and CTT40 (on average by $2 \%$ ). Finally, in Mongiana, the frequency of hemicryptophytes increased significantly $(p<0.01)$ only after the innovative treatment.

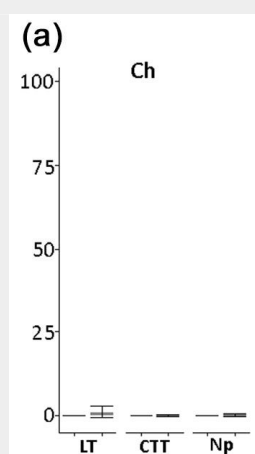

(b)

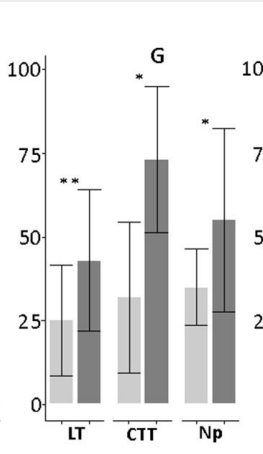

Life form cover (\%)

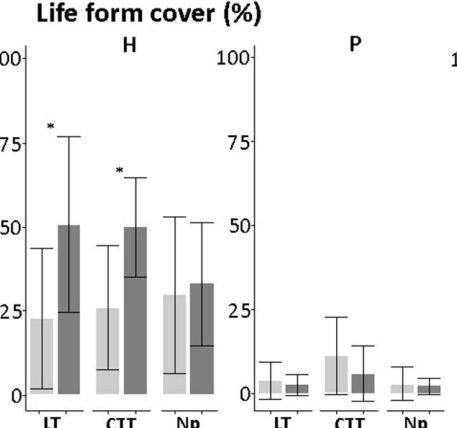

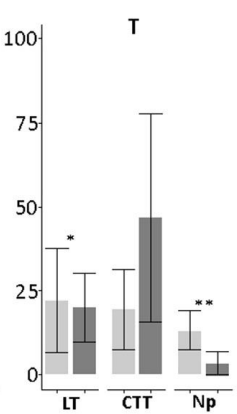
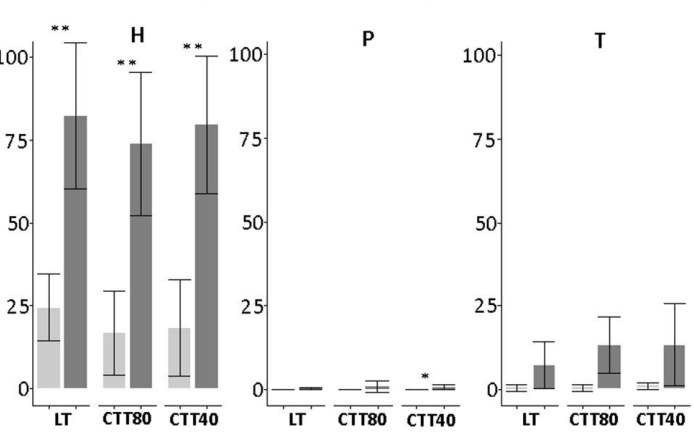

(c)
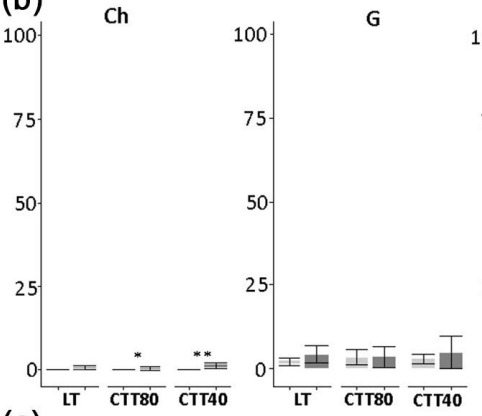

G
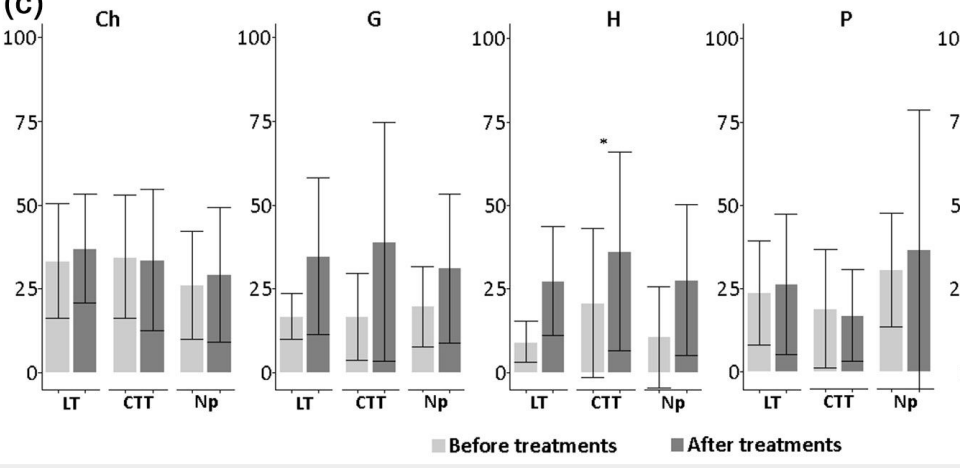

Fig. 6 - Cover (\%) of life forms recorded before and after the silvicultural treatment in the three study sites, with related statistical comparisons. (Ch): chamephytes; (G): geophytes; (H): hemicryptophytes; $(P)$ : phanerophytes; $(\mathrm{T})$ : terophytes; (CTT): Crop tree thinning; (LT): Thinning from below; (Np): No practices; $\left(^{*}\right)$ : $p<0.05 ;(* *): p<0.01$. 
After the silvicultural treatment, significant changes also affected the total cover of each life form group (Fig. 6). In all sites, the cover of hemicryptophytes increased after innovative treatment. This increase was particularly evident in Chiarano-Sparvera $(p<0.01)$ after all the silvicultural treatment. In Cansiglio, the cover of geophytes reached high values after all the silvicultural treatment, while the cover of therophytes was low in the control plots (on average by $3.37 \%$ ). In Chiarano-Sparvera, after the CTT40 treatment, a significant increase in cover of phanerophytes $(p<0.05)$ and chamaephytes $(p<0.01)$ was observed; this latter biological group increased $(p<0.05)$ also after the CTT80 treatment. In Mongiana, after innovative treatment, an increase in cover of hemicryptophytes and terophytes was recorded $(p<0.05)$.

\section{Discussion}

\section{Deadwood and microhabitats}

The early response of Italian mountain beech forests to the innovative silvicultural treatment applied in this study was mainly related to the increase and diversification of deadwood, and the creation of favourable conditions for the establishment of new microhabitats. Several authors have emphasised that silvicultural treatment should mimic natural disturbance (Haila 1994) and highlighted the need for innovative management measures to conserve biodiversity and increase naturalness. We propose crop tree thinning, selective thinning from above, releasing a variable number of candidate trees, as innovative and diversification silvicultural practices aimed at increasing deadwood quantity and microhabitat density in these mountain beech forests, in order to combine forest productivity and carbon storage, and promote forest biodiversity. In particular, the novelty of the method lies in the number of candidate trees which is rather low, since only 40-50 or 80 trees were selected. In all experimental sites, local traditions and past habits influenced the impact of silvicultural treatment to a variable extent, further diversifying deadwood composition, in particular that of coarse woody debris and stump components. As regards the stumps, it is worth considering that our findings refer to the moment shortly after the application of silvicultural treatments (Harmon et al. 1986). Therefore, it is possible that some of these stumps are still able to re-sprout, thus in this case their number would be overestimated. In one area treated with the innovative practice, the cutting and releasing of several medium sized trees on the forest floor, as future decaying deadwood, has favoured the increase of coarse debris occurrence (Rouvinen \& Kuuluvainen 2001), although the high standard deviation highlighted an irregular distribution of downed dead trees.

The integration of other practices, in addition to felled trees left in situ, may help promote biodiversity. In the long term, the girdling of trees during the thinning operations may increase the number of standing dead trees and deadwood occurrence, favouring a greater diversity of flora and fauna (Kerr 1999). Other studies have reported the increasing occurrence of deadwood after cutting, suggesting that deadwood fraction initially declines in a felled forest, due to its post-harvesting removal, but returns to pre-logging values after about 50 years. Although partial harvests generally cause minor disturbances to ecosystem functions and services, the long-term impact of even light partial harvesting on coarse woody debris stocks and distribution can be observed (Morrissey et al. 2014).

In this study, we found, on average, $17 \mathrm{~m}^{3}$ ha $^{-1}$ of deadwood, of which $75 \%$ was composed by stumps. Stumps, in fact, are directly related to management practices, as they are generally harvesting residuals (Burrascano et al. 2008). However, it is not obvious that the volume of stumps were significantly higher following the crop tree thinning and low thinning treatments, while they did not vary for the control without intervention. In fact, natural disturbances play their part in tree fall and thus in the creation of new stumps of natural origin, also in unmanaged stands (Lombardi et al. 2008a).

In beech forests of the central Apennines, Lombardi et al. (2008b) the amount of deadwood ranges from $25 \mathrm{~m}^{3} \mathrm{ha}^{-1}$ in unmanaged stands to $5 \mathrm{~m}^{3} \mathrm{ha}^{-1}$ in managed ones, in line with our results. On average, the Italian National Forest Inventory estimates deadwood occurrence in Italy equal to $8.8 \mathrm{~m}^{3} \mathrm{ha}^{-1}$. Mediterranean forests have a recent history of sustainable forest management practices, with deadwood input so far being limited to small, rapidly decaying material. When low thinning treatment was applied, the coarse woody debris component decreased significantly and downed dead trees disappeared. In these forests, lying deadwood was traditionally removed as firewood and/or to reduce the presence of physical obstacles to forestry operations (Pedlar et al. 2002).

Due to the absence of human pressure and thanks to the presence of old trees, an increase of some microhabitats was observed, only a short time after treatment; in particular fungal infections, cracks, cavities, bark loss, and woody debris with saproxylic insect holes. Beside deadwood occurrence, monitoring microhabitats in forest stands was an important option for validating the presence of a wide range organisms, since their incidence is strongly related to forest species (Harmon et al. 1986, Remm et al. 2006), as well as the efficacy of silvicultural treatments in the maintenance of forest biodiversity. However, their relationship to microhabitats with silvicultural treatments was different from that of the deadwood. In general, thinning from below did not produce any marked decrease of microhabitats, and therefore this method can be considered sustainable as thinning from above for preserving biodiversity in managed beech forests. Notwithstanding this innovative treatment aimed at increasing the occurrence of microhabitats, this was not the case in the studied forest stands. Innovative treatments CTT40 and CTT80 even caused a significant decrease in the number of microhabitats. It must be pointed out that, due to the time needed for the establishment and diversification of microhabitats, these results may vary in a long-term perspective. For example, Larrieu et al. (2017) have observed significantly higher microhabitat density and diversity in beech forest stands harvested 10-15 years before surveying, while no differences in areas harvested 1-5 years before surveying, with marked differences occurring only $70-80$ years after the last silvicultural intervention. Vuidot et al. (2011) have demonstrated that, whatever form of management, the number and type of microhabitats are mainly influenced by individual tree features, and the probability of microhabitat density is the same for similar trees.

In addition to forest operations, deadwood presence can also be linked to a major recurrence of natural disturbances (wind, fungal infections, etc.) and the consequent mortality of trees, which in turn may increase the accumulation of deadwood and microhabitat density, with further implications on these forest types. The implementation of innovative treatment mimicking natural forest disturbance (opening of canopy gaps) represents a valid alternative, at least for the investigated forest types, to establish the actual environmental conditions to preserve or maybe increase, over a long term prospective, the levels of forest naturalness and sustainability.

\section{Understory vegetation and life forms}

In the Cansiglio and Chiarano-Sparvera sites, the floristic richness was higher only in areas affected by the innovative treatment. The intensity of this treatment induced a significant decrease in tree density, creating gaps and increasing the input of light radiation, useful to the rapid colonisation of gaps (Kutnar et al. 2015). Within forest canopy gaps, the availability of nutrients to understory vegetation can be higher, due to limited competition and increased insolation and temperature (Fahey \& Puettmann 2007), although in the Mediterranean environment an increase in water loss can also be expected, due to higher evaporation rates. In Mongiana, significant differences were not found in the number of species after the application of silvicultural treatments. Studies evaluating selective logging and thinning treatments also showed inconsistent effects on understory vegetation richness (Paillet et al. 2010). These results can be influenced by the forest type examined. In fact, the higher het- 
erogeneity of forest stands observed in Mongiana before the implementation of silvicultural treatment did not implicate sig nificant changes in tree density, so that the species richness was not affected.

Although species richness and forest management are strongly interconnected, a few studies have been conducted on the responses of the understory vegetation to the thinning activities. Forest management includes various methods of logging, which can differentially influence the understory vegetation. For example, a peculiar cutting scheme may affect plant cover differently from species richness (Knapp et al. 2013). In this study, the implementation of different silvicultural treatments (thinning intensity and type) caused specific impact on the composition of understory vegetation.

Several studies have shown that floristic richness is inversely proportional to tree density. In addition, significant differences were observed by analysing the cover values of herbaceous species in relation to the type of silvicultural treatment. In Cansiglio and Chiarano-Sparvera, plant cover was higher in the areas where both thinning from below and crop tree thinning were implemented. In these areas, a rapid colonisation of gaps was recorded and, besides the nemoral species, forest edge species also appeared in the mixed understory vegetation. Furthermore, a significant increase in understory plant cover was observed at Mongiana site, also in the control plots. This increase can probably be influenced by the specific microclimate of this Mediterranean mountain forest stand, where herbaceous species have adapted to shady and humid conditions and may find optimal growth environments.

Concerning life forms, different trends among the three sites were observed. In Cansiglio, a significant increase in the frequency of geophytes was observed in the control plots, while the cover of these species (e.g., Anemone nemorosa L., Anemone trifolia L.) increased in all three types of silvicultural treatment. In nearby Alpine forests, Alberti et al. (2013) found that the abundance of geophytes groups is strictly related to the degree of shading of the forest stand (e.g., tree density, canopy cover). In our site, the frequency of hemicryptophytes decreased in the control plots, while the cover of these species increased after thinning from below and crop tree thinning treatment. Biswas \& Mallik (2010) found a significant increase in graminoids (hemicryptophytes), but also a significant decrease in tree species, with increasing disturbance intensity. The consequences of disturbances on biodiversity are complex and are influenced by disturbance characteristics (type, intensity, etc.) and community traits (composition, richness, etc.). The consequences of severe disturbances may even be negligible on understory individuals if, for example, increased mortality rates of canopy trees are accompanied by an increase in available resources (e.g., nu- trients, light, etc.) and there are available recruits. Increasing overall species richness and decreasing total ecosystem carbon can be expected under a climate change scenario (Thom \& Seidl 2016). Yet, in European forests, the nature and regime of disturbances have changed through time, and sustainable silvicultural practices need to take natural disturbance dynamics into account to better manage forests for both production and biodiversity.

The frequency of therophytes increased after crop tree thinning treatment, but decreased in the control plots, probably because of the continuity of the forest cover. Graae \& Sunde (2000) have reported that therophytes are more common in managed than in unmanaged forests. In Chiarano-Sparvera, the dominance of hemicryptophytes was higher after CTT80 and CTT40 treatments than in the control plots, whereas the occurrence of geophytes was lower after treatment in all the study sites. The reduction of tree cover and the creation of canopy gaps increased the light radiation on the forest floor, in turn reducing the frequency of geophytes. Moreover, after CTT80 and CTT40 treatments, the high frequency of hemicryptophytes was strictly connected to the establishment of species typical to grazed areas, surrounding the studied forests. Among the typical species of pastures, there were Dactylis glomerata L., Cirsium tenoreanum Petr., Capsella bursa-pastoris (L.) Medik. These species generally take advantage from disturbances, either natural or anthropogenic, due to gap opening processes. In Chiarano-Sparvera, a significant increase in the cover of chamaephytes was recorded after both the CTT80 and CTT40 treatment. This increase was related to the presence of Trifolium pratense L., which was not detected before the implementation of the silvicultural treatment. Such species is commonly found in nearby meadows and pastures. In addition, in CTT40 areas, an increase in the cover of phanerophytes was also found, as a further consequence of thinning practices. In Mongiana, after the crop tree thinning treatment, higher frequency and coverage of therophytes and hemicryptophytes were observed. Hodgson et al. (2005) observed that annual species (therophytes) and graminoids (hemicryptophytes) are dominant in disturbed habitats, but also where trees are prevalent.

\section{Conclusions}

This study confirms the importance of deadwood, microhabitats and understory vegetation as biodiversity indicators and proxies, when related to silvicultural strategies for mountain beech forests. After two years from treatment, the management options lead to different short-term responses of the studied parameters. Crop tree thinning treatments increased deadwood quantities, while thinning from below favoured only the presence of stumps. Microhabitats increased in number where silvicultural intervention was postponed and remained unvaried after the LT intervention. CTT treatment created ecological conditions which were beneficial to the establishment of microhabitats and their development in the future. Furthermore, a significant increase in floristic richness was observed after CTT treatment, in all the studied forest stands. Finally, further monitoring activities in the same study areas will be desirable in the next 5-10 years, to further investigate the timber quality after thinning at the rotation age.

The results point to adaptive forest management strategies leading to sustainable utilisation rates that allow for maintaining forest productivity and increasing biodiversity conservation. Although most studies of biodiversity-oriented management strategies focus on forest biodiversity indicators, which are separate from each other, integrating multiple indicators proved more practical in targeting sustainable silvicultural treatment and its associated functions.

\section{Acknowledgements}

This research received funding from the EU's Life Environment financial instrument within ManFor C.BD Project (LIFEog ENV/IT 1000078). The research is linked to activities conducted within the COST (European Cooperation in Science and Technology) Action CLIMO ("Climate-Smart Forestry in Mountain Regions" - CA15226) financially supported by the EU Framework Programme for Research and Innovation HORIZON 2020. We thank Prof. Edward Parker for correcting and improving the English text.

\section{Authors' contribution}

SDL and AV have equally contributed to the writing of this paper.

\section{References}

Alberti G, Boscutti F, Pirotti F, Bertacco C, De Simon G, Sigura M, Bonfanti P (2013). A LiDARbased approach for a multi-purpose characterization of Alpine forests: an Italian case study. iForest 6: 156-168. - doi: 10.3832/iforo876-006 Becagli C, Puletti N, Chiavetta U, Cantiani P, Salvati L, Fabbio G (2013). Early impact of alternative thinning approaches on structure diversity and complexity at stand level in two beech forests in Italy. Annals of Silvicultural Research 37: 55-63. [online] URL: http://www.research gate.net/publication/261027022

Biswas SR, Mallik AU (2010). Disturbance effects on species diversity and functional diversity in riparian and upland plant communities. Ecology 91: 28-35. - doi: 10.1890/08-0887.1

Burrascano S, Lombardi F, Marchetti M (2008). Old-growth forest structure and deadwood: Are they indicators of plant species composition? A case study from central Italy. Plant Biosystems 142: 313-323. - doi: 10.1080/11263500 802150613

Dearden FM, Wardle DA (2008). The potential for forest canopy litterfall interception by a dense fern understorey, and the consequences 
for litter decomposition. Oikos 117: 83-92. - doi: 10.1111/j.2007.0030-1299.16136.x

Di Salvatore U, Tonti D, Chiavetta U, Cantiani P, Fabbio G, Becagli C, Bertini G, Sansone D, Skudnik M, Kobal M, Kutnar L, Ferreira A, Kobler A, Kovač M, Ferretti F (2016). ManFor CBD sites and the drivers of forest functions. Italian Journal of Agronomy 11 (S1): 64-95.

Fahey RT, Puettmann KJ (2007). Ground-layer disturbance and initial conditions influence gap partitioning of understorey vegetation. Journal of Ecology 95: 1098-1109. - doi: 10.1111/j.13652745.2007.01283.x

Gamborg C, Larsen JB (2003). "Back to nature" a sustainable future for forestry? Forest Ecology and Management 179: 559-571. - doi: 10.1016/S0378-1127(02)00553-4

Gendron F, Messier C, Comeau PG (1998). Comparison of various methods for estimating the mean growing season percent photosynthetic photon flux density in forests. Agricoltural Forest and Meteorology 92: 55-70. - doi: 10.1016/ S0168-1923(98)00082-3

Graae BJ, Sunde PB (2000). The impact of forest continuity and management on forest floor vegetation evaluated by species traits. Ecography 23: 720-731. - doi: 10.1111/j.1600-0587.2000. tboo315.x

Guby NB, Dobbertin M (1996). Quantitative estimates of coarse woody debris and standing dead trees in selected Swiss forests. Global Ecology and Biogeography Letters 5: 327-341. doi: $10.2307 / 2997588$

Haila Y (1994). Preserving ecological diversity in boreal forests: ecological background, research, and management. Annales Zoologici Fennici 31: 203-217. [online] URL: http://www. jstor.org/stable/23735511

Harmon ME, Franklin JF, Swanson FJ, Sollins P, Gregory SV, Lattin JD, Lienkaemper GW (1986). Ecology of coarse woody debris in temperate ecosystems. Advances in Ecological Research 15: 133-302. - doi: 10.1016/So065-2504(08)60121$\mathrm{X}$

Herbeck LA, Larsen DR (1999). Plethodontid salamander response to silvicultural practices in Missouri Ozark forests. Conservation Biology 13: 623-632. - doi: 10.1046/j.1523-1739.1999.980 97. $\mathrm{x}$

Hodgson JG, Grime JP, Wilson PJ, Thompson K, Band SR (2005). The impacts of agricultural change (1963-2003) on the grassland flora of Central England: processes and prospects. Basic and Applied Ecology 6: 107-118. - doi: 10.1016/j.baae.2005.01.009

Humphrey JW, Davey S, Peace AJ, Ferris R, Harding K (2002). Lichens and bryophyte communities of planted and semi-natural forests in Britain: the influence of site type, stand structure and deadwood. Biological Conservation 107: 165-180. - doi: 10.1016/Sooo6-3207(02)000 57-5

Kern CC, Montgomery RA, Reich PB, Strong TF (2014). Harvest-created canopy gaps increase species and functional trait diversity of the forest ground-layer community. Forest Science 60: 335-344. - doi: 10.5849/forsci.13-015

Kerr G (1999). The use of silvicultural systems to enhance the biological diversity of plantation forests in Britain. Forestry 72: 191-205. - doi: 10.1093/forestry/72.3.191
Khanina L, Bobrovsky M, Komarov A, Mikhajlov A (2007). Modeling dynamics of forest ground vegetation diversity under different forest management regimes. Forest Ecology and Management 248: 80-94. - doi: 10.1016/j.for eco.2007.03.021

Knapp EE, Skinner CN, North MP, Estes BL (2013). Long-term overstory and understory change following logging and fire exclusion in a Sierra Nevada mixed-conifer forest. Forest Ecology and Management 310: 903-914. - doi: 10.1016/j.foreco.2013.09.041

Kutnar L, Eler K, Marinšek A (2015). Effects of different silvicultural measures on plant diversity the case of the Illyrian Fagus sylvatica habitat type (Natura 2000). iForest 9: 318-324. - doi: 10.3832/ifor1587-008

Larrieu L, Cabanettes A (2012). Species, live status, and diameter are important tree features for diversity and abundance of tree microhabitats in subnatural montane beech-fir forests. Canadian Journal of Forest Research 42: 14331445. - doi: 10.1139/x2012-077

Larrieu L, Cabanettes A, Gouix N, Burnel L, Bouget C, Deconchat M (2017). Development over time of the tree-related microhabitat profile: the case of lowland beech-oak coppice-withstandards set-aside stands in France. European Journal of Forest Research 136: 37-49. - doi: 10.1007/s10342-016-1006-3

Lindenmayer DB, Margules CR, Botkin DB (2000). Indicators of biodiversity for ecologically sustainable forest management. Conservation Biology 14: 941-950. - doi: 10.1046/j.15231739.2000.98533.x

Lombardi F, Cherubini P, Tognetti R, Marchetti M (2008a). Tree rings assess deadwood decay rates in beech and silver fir forests in Central Apennines (Molise, Italy). Canadian Journal of Forest Research 38: 821-833. - doi: 10.1139/Xo7195

Lombardi F, Lasserre B, Tognetti R, Marchetti M (2008b). Deadwood in relation to stand management and forest type in Central Apennines (Molise, Italy). Ecosystems 11: 882-894. - doi: 10.1007/s10021-008-9167-7

Lombardi F, Lasserre B, Chirici G, Tognetti R, Marchetti M (2012). Deadwood occurrence and forest structure as indicators of old-growth forest conditions in Mediterranean mountainous ecosystems. Ecoscience 19: 344-355. - doi: 10.2980/19-4-3506

Lombardi F, Marchetti M, Corona P, Merlini P, Chirici G, Tognetti R, Burrascano S, Alivernini A, Puletti N (2015). Quantifying the effect of sampling plot size on the estimation of structural indicators in old-growth forest stands. Forest Ecology and Management 346: 89-97. - doi: 10.1016/j.foreco.2015.02.011

MacDicken KG, Sola P, Hall JE, Sabogal C, Tadoum M, De Wasseige C (2015). Global progress toward sustainable forest management. Forest Ecology and Management 352: 47-56. - doi: 10.1016/j.foreco.2015.02.005

Michel AK, Winter S (2009). Tree microhabitat structures as indicators of biodiversity in Douglas-fir forests of different stand ages and management histories in the Pacific Northwest, USA. Forest Ecology and Management 257: 1453-1464. - doi: 10.1016/j.foreco.2008.11.027 Mikusinski G, Angelstam P (1997). European woodpeckers and anthropogenic habitat change: a review. Vogelwelt 118: 277-283. [online] URL: http://www.researchgate.net/publica tion/240310747

Morrissey RC, Jenkins MA, Saunders MR (2014). Accumulation and connectivity of coarse woody debris in partial harvest and unmanaged relict forests. PLoS ONE 9: e113323. - doi: 10.1371/journal.pone.0113323

Nilsson MC, Wardle DA (2005). Understory vegetation as a forest ecosystem driver: evidence from the northern Swedish boreal forest. Frontiers in Ecology and the Environment 3: 421428. - doi: 10.1890/1540-9295(2005)003[0421:UV AAFE]2.0.CO;2

Odor P, Standovár T (2001). Richness of bryophyte vegetation in near-natural and managed beech stands: the effects of management-induced differences in dead wood. Ecological Bulletins 49: 219-229. [online] URL: http:// www.jstor.org/stable/20113278

Paillet Y, Bergès L, Hjältén J, Odor P, Avon C, Bernhardt-Römermann M, Kanka R (2010). Biodiversity differences between managed and unmanaged forests: meta-analysis of species richness in Europe. Conservation Biology 24: 101112. - doi: 10.1111/j.1523-1739.2009.01399.X

Paillet Y, Pernot C, Boulanger V, Debaive N, Fuhr M, Gilg O, Gosselin F (2015). Quantifying the recovery of old-growth attributes in forest reserves: A first reference for France. Forest Ecology and Management 346: 51-64. - doi: 10.1016/j.foreco.2015.02.037

Pecl GT, Araújo MB, Bell JD, Blanchard J, Bonebrake TC, Chen IC, Clark TD, Colwell RK, Danielsen $F$, Evengård $B$, Falconi $L$, Ferrier $S$, Frusher S, Garcia RA, Griffis RB, Hobday AJ, Janion-Scheepers C, Jarzyna MA, Jennings S, Lenoir J, Linnetved HI, Martin VY, McCormack PC, McDonald J, Mitchell NJ, Mustonen T, Pandolfi JM, Pettorelli N, Popova E, Robinson SA, Scheffers BR, Shaw JD, Sorte CJB, Strugnell JM, Sunday JM, Tuanmu MN, Vergés A, Villanueve C, Wernberg T, Wapstra E, Williams SE (2017). Biodiversity redistribution under climate change: impacts on ecosystems and human well-being. Science 355 (6332): eaaig214. - doi: 10.1126/science.aai9214

Pedlar JH, Pearce JL, Venier LA, McKenney DW (2002). Coarse woody debris in relation to disturbance and forest type in boreal Canada. Forest Ecology and Management 158: 189-194. doi: 10.1016/S0378-1127(00)00711-8

Pignatti S (1982). Flora d'Italia (3 vol) [Italian Floristic Atlas (Vol. 3)]. Ed. Agricole, Bologna, Italy, pp. 595. [in Italian]

Remm J, Lohmus A, Remm K (2006). Tree cavities in riverine forests: what determines their occurrence and use by hole-nesting passerines? Forest Ecology and Management 221: 267-277. doi: 10.1016/j.foreco.2005.10.015

Rouvinen S, Kuuluvainen T (2001). Amount and spatial distribution of standing and downed dead trees in two areas of different fire history in a boreal Scots pine forest. Ecological Bulletins 49: 115-127. [online] URL: http://www. jstor.org/stable/20113269

Siitonen J (2001). Forest management, coarse woody debris and saproxylic organisms: Fennoscandian boreal forests as an example. Ecological Bulletins 49: 11-41. [online] URL: http:// 
www.jstor.org/stable/20113262

Tabacchi G, Di Cosmo L, Gasparini P (2011). Aboveground tree volume and phytomass prediction equations for forest species in Italy. European Journal of Forest Research 130: 911-934. - doi: 10.1007/s10342-011-0481-9

Thom D, Seidl R (2016). Natural disturbance im- pacts on ecosystem services and biodiversity in temperate and boreal forests. Biological Reviews 91: 760-781. - doi: 10.1111/brv.12193

Vuidot A, Paillet Y, Archaux F, Gosselin F (2011). Influence of tree characteristics and forest management on tree microhabitats. Biological Conservation 144: 441-450. - doi: 10.1016/j.bio con.2010.09.030

Winter S, Möller GC (2008). Microhabitats in lowland beech forests as monitoring tool for nature conservation. Forest Ecology and Management 255: 1251-1261. - doi: 10.1016/j.foreco.2007. 10.029 